\title{
From spatial variation of fracture patterns to fold kinematics: A geomechanical approach
}

\author{
N. Bellahsen, ${ }^{1}$ P. E. Fiore, and D. D. Pollard \\ Department of Geological and Environmental Sciences, Stanford University, Stanford, California, USA \\ Received 27 July 2005; revised 8 November 2005; accepted 15 November 2005; published 18 January 2006.
}

[1] A vertical, compression-parallel joint set apparently formed at Sheep Mountain Anticline (SMA) during the early Laramide orogeny, prior to significant folding. Field data indicate that these joints occur in fewer locations in the forelimb than in the hinge and backlimb. Using threedimensional elastic dislocation models, we show that early slip along an underlying thrust fault can locally perturb the surrounding stress field, inhibiting joint formation above the fault. Thus, we are able to constrain the forelimb kinematics finding that the forelimb was originally located in the hangingwall, above the thrust fault. Furthermore the mode of folding at SMA is constrained: the anticline developed with a fixed hinge and rotating limbs, while the underlying basement rocks deformed internally. Citation: Bellahsen, N., P. E. Fiore, and D. D. Pollard (2006), From spatial variation of fracture patterns to fold kinematics: A geomechanical approach, Geophys. Res. Lett., 33, L02301, doi:10.1029/2005GL024189.

\section{Introduction}

[2] The growth of basement fault-cored anticlines have often been interpreted using the classical forced fold model [Cosgrove and Ameen, 2000; Stearns, 1978]. In this model, the basement is very locally deformed along a thrust fault separating two rigid blocks. The hanging wall basement block is translated upward deforming the overlying sedimentary layers. In this model, the shape of the fold is determined by the geometry of the underlying thrust fault. A planar fault creates a monoclinal fold [Reches, 1978] and a listric fault creates backlimb rotation, which results in the development of an anticline rather than a monocline [Erslev, 1986]. On the other hand, several studies [Blackstone, 1986; Wise and Obi, 1992; Stone, 1993] have shown, mainly from subsurface data, that basement blocks may be significantly deformed (i.e., curved basement-cover interface). In this case, the backlimb rotation can be attributed to the deformed basement-cover interface and does not require the underlying fault to be listric. In other examples, using field data, Casas et al. [2003] and Garcia and Davis [2004] showed that basement blocks surrounding thrust faults deformed during compression. Thus, the shape of a fold does not only depend on the fault geometry, but also on the distribution of the deformation in the cover and the basement rocks.

\footnotetext{
${ }^{1}$ Now at Laboratoire de Tectonique, Université Pierre et Marie Curie, Paris, France.
}

Copyright 2006 by the American Geophysical Union. 0094-8276/06/2005GL024189
[3] It is noteworthy that basement internal deformation often is neglected in kinematic [e.g., Erslev, 1991; McConnell, 1994] and numerical models [Johnson and Johnson, 2002]. This can be partially attributed to the fact that a clear understanding of how internal deformation is distributed in the basement is lacking. On the other hand, rock mechanics data [Bieniawski, 1984] and calculations from in situ Vp and Vs [Mavko et al., 1998; Boness and Zoback, 2004] values indicate that the modulus of elasticity for sedimentary and crystalline rocks overlap, ranging from approximately 1 to $90 \mathrm{GPa}$ and 10 to $110 \mathrm{GPa}$, respectively, so basement rocks should not necessarily be taken as stiffer, much less as rigid. While the assumption of a rigid basement may be justified for the sake of a simple model, it should be clear that the forced fold model is an incomplete model for basement involved folds. For these reasons, we believe that field studies are important to interpret the possible mechanical behavior of both the basement and cover rocks.

[4] In this study, we investigate the fold kinematics at Sheep Mountain Anticline (SMA), Wyoming, to determine if fold evolution is more compatible with a rigid basement or a non-rigid basement. To constrain the fold kinematics, we use a set of early Laramide (early-folding) joints (formed perpendicular to the least compressive stress) as passive markers that define specific structural locations on the fold and then determine where those markers were before folding. Bellahsen et al. [2006] showed that these joints are significantly less numerous in the fold forelimb and suggested the influence of stress perturbations caused by slip on the underlying basement thrust fault.

[5] In this paper, we use three-dimensional elastic models (Poly3D [Thomas, 1993]) to study how early thrust fault movements perturb the surrounding stress field. Such stress perturbations around faults in other regions have been derived from elastic models and compared to available field data [e.g., Kattenhorn et al., 2000; Bourne and Willemse, 2001; Maerten et al., 2002]. Following a similar procedure allows us to determine the location of a zone at SMA where joint formation would be inhibited. The observed zone of limited jointing in the fold forelimb provides an important constraint on the fold kinematics.

\section{Geological Setting}

[6] Sheep Mountain Anticline (SMA) is a NW-SE trending Laramide fold (Figure 1a) located on the eastern edge of the Bighorn Basin, Wyoming. The Laramide orogeny started at the end of the Cretaceous and was characterized by a NE-trending compression [Engebretson et al., 1985; 


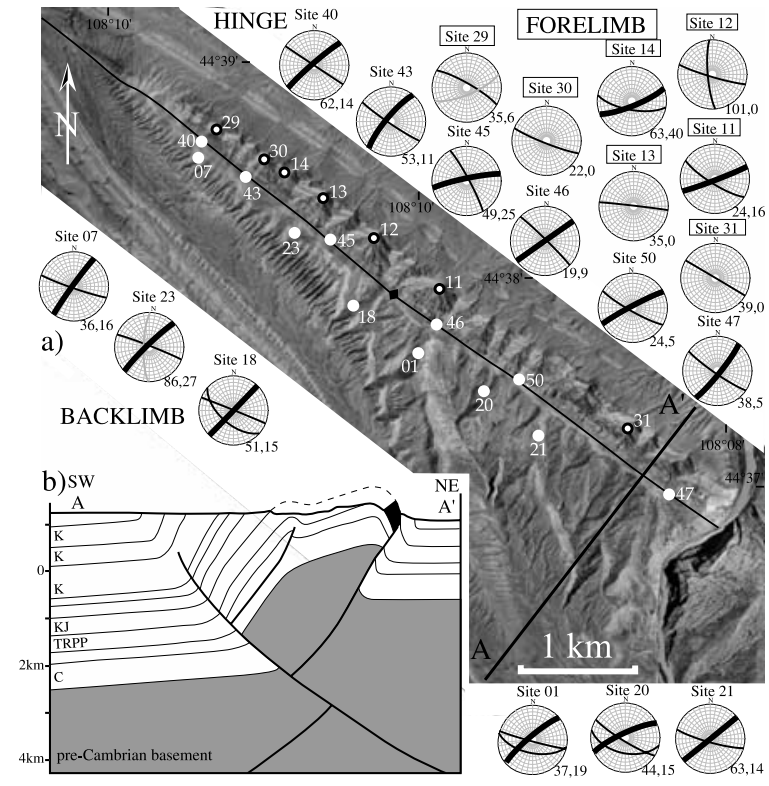

Figure 1. (a) Fracture data at Sheep Mountain Anticline. Stereonets of fracture measurements are rotated to paleohorizontal and numbers to the lower right of each stereonet give first the total number of fractures and second the number of set II fractures. Bold great circles represent joints striking NE-SW. These fractures comprise a major fracture set at all localities in the backlimb and the hinge, but they are notably less abundant or absent at localities in the forelimb. Sample locations and stereonets in the forelimb are highlighted by larger black and white dots on the map and a rectangle around their name above the stereonets, respectively. (b) Cross-section from Stanton and Erslev [2004] running from A-A ${ }^{\prime}$ in Figure 1a. The dark rectangle represents the forelimb where NE-SW joints are less abundant. C: Cambrian. TRPP: Trias-Permian-Pennsylvanian. K: Cretaceous. J: Jurassic.

Bird, 2002] that apparently generated SMA, a basement fault-cored asymmetric fold.

[7] Fracture measurements were collected in Pennsylvanian sandstone layers (Tensleep Fm.) that are a few meters thick [Bellahsen et al., 2006]. These sandstones are located within a competent assemblage of sandstones and limestones that is both underlain and overlain by thick sequences of less competent shales. Collectively the sedimentary layers (about $3000 \mathrm{~m}$ thick) lie above granitic basement rocks [see Hennier and Spang, 1983; Rioux, 1994; Forster et al., 1996]. Several fracture sets are observed at Sheep Mountain anticline [Bellahsen et al., 2006]: ESE-trending bed-perpendicular pre-Laramide fractures, NE-trending bed-perpendicular early Laramide joints, SE-trending folding-related joints, and ESE-trending vertical late joints (oblique to the bedding). The NE-trending joints are interpreted to have formed during the early Laramide orogeny, parallel to the compression, when bedding was subhorizontal. These joints are present in the backlimb, the hinge, and the northern nose, but are observed in fewer locations in the forelimb (Figure 1a). This fracture set can be found in the syncline northeast of SMA. We hypothesize that their heterogeneous distribution over the anticline is related to the influence of active faults during the time of their formation, the early-folding period.

\section{Mechanical Model}

\subsection{Model Setup}

[8] We carried out the mechanical modeling using Poly3D [Thomas, 1993], a three-dimensional boundary element program based on the displacement discontinuity method and the governing equations of linear elasticity. Single slip events or a series of events are considered within which a complete stress relaxation occurs between each event. Linear elasticity is well suited for our study since we only model the very first steps of deformation caused by the motion along the thrust fault. The underlying fault at Sheep Mountain is interpreted as a SW-dipping (around $50^{\circ}$ ) basement fault [Stanton and Erslev, 2004] (Figure 1b). Fault length in the dip direction is arbitrarily set to $5 \mathrm{~km}$ and the fault is given boundary conditions of zero in-plane shear traction and zero fault normal displacement.

[9] Based on the stratigraphy, at the beginning of the Laramide orogeny, the Tensleep formation was at a depth of about $2200 \mathrm{~m}$ and the base of the sedimentary cover at $3000 \mathrm{~m}$ (Figure 2a). Gravity provides an ambient lithostatic stress state based on an average density of $2700 \mathrm{~kg} /$ $\mathrm{m}^{3}$. The Laramide orogeny is modeled by applying a horizontal contraction in the NE direction of magnitude 0.1 (perpendicular to the fault strike) and an extension of magnitude 0.01 in the NW direction. We interpret vertical joints to have formed striking to the NE, during the beginning of the Laramide orogeny, so the principal horizontal stress in the NW direction must have been an effective tension. Because the relative magnitudes of the boundary strains are poorly constrained, we interpret the model results qualitatively. A zone of more compressive stress relative to another suggests that the formation of joints in this zone would be inhibited. The Young's modulus was set to $10 \mathrm{GPa}$, the Poisson ratio to 0.25 .

\subsection{Results}

[10] The results are described in terms of perturbations of the horizontal least compressive principal stress (Figure 2a) that controls the formation of vertical joints striking in the NE direction. This stress component is positive (i.e., tensile) at the surface and becomes more compressive with depth, due to the overburden load. In the model fault footwall, near the upper tip line, slip creates a zone of tensile stress (Figure 2a), while in the hangingwall a zone of compression and joint inhibition is created and is located in the forelimb of the fold. Above the compressive zone, near the surface, a tensional zone can be observed due to the free surface. We also present similar results from models where the depth and down dip length of the fault and the boundary conditions were varied (Figure 2b).

\section{Implications and Discussion}

[11] Elastic modeling indicates that a zone, where the least compressive stress is more compressive than in the surrounding area, is located above the fault within the hanging wall (Figure 2). In this zone, the formation of joints striking parallel to the maximum compression direction would be inhibited. In the field, we observed a 


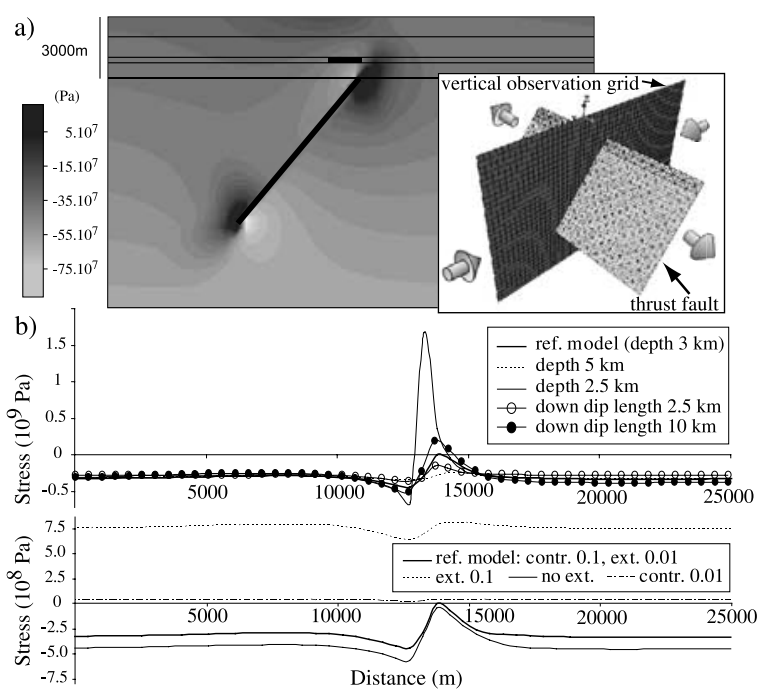

Figure 2. Elastic model. (a) Model geometry and stresses. A vertical plane perpendicular to fault strike and located at its center is designated as an observation grid. The arrows represent the remote extension and contraction. On the observation grid, the least compressive principal stress trends perpendicular to the grid and controls the formation of new joints trending parallel to the grid. A zone of enhanced compressive stress is located just behind the upper fault tip line in the hangingwall (compressive quadrant, black rectangle). (b) Results of models in which parameters were varied. The least compressive stress at a depth of 2200 $\mathrm{m}$, along a profile perpendicular to the fault (at its center), is plotted (the hanging wall on the left). Varying the depth (of the fault upper tip line) and the fault length in dip direction (plot 1) does not affect the existence of the zone of elevated compression, represented by the minima in these plots. However, shallow depth and large down dip fault length produce high amplitude tensile zones. The smaller the depth to down dip length ratio, the larger the perturbation. The strain boundary conditions do have an effect (plot 2): while applying no extension parallel to the fault does not significantly change the result, a large extension parallel to the fault or a lesser contraction perpendicular to the strike of the fault produces flatter curves that are not consistent with a zone of joint inhibition. Results not shown here: Changing the Young's modulus and/or the Poisson ratio does not affect the location and the horizontal extent of the stress perturbation, although with a small Poisson ratio the stress is tensile everywhere and with a large Poisson ratio, it is compressive everywhere. A larger or shallower fault dip decreases the value of the stress anomaly, as does variation in traction along the fault plane.

similar zone in the forelimb of SMA, where joints parallel to the compression direction are sparse. If these two zones correspond to each other, we can conclude that the forelimb was located above the fault in the hangingwall of the thrust fault in the early stages of the folding.

[12] This kind of constraint enables us to establish the mode of folding. In the case of SMA, the basement fault most likely formed prior to the Laramide orogeny (Figure 3a) [see Stanton and Erslev, 2004; Bellahsen et al., 2006]. With the onset of NE compression, the fault was reactivated (Figure 3b), perturbing the stress field in its vicinity. The stress perturbation described here is based on a model of a basement that has the same elastic stiffness as the sedimentary cover. We cannot account for bedding-parallel slip, which may influence the inhibition of jointing and should be explored in the future. However, the basement is not rigid, such that initial slip along the thrust fault is accompanied by deformation everywhere in the vicinity of the fault, including the basement. We expect that such models with a stiffer (but not rigid) basement may produce a less penetrative deformation within the basement but greater slip along the fault, and thereby lead to a similar kinematics.

[13] With ongoing regional contraction, the fold developed above the fault, within the hangingwall, because the forelimb was located above the fault before folding (Figure 3c and 3d). Seismic lines [Stanton and Erslev, 2004; D. S. Stone, personal communication] in close proximity to the fold show that the fold is above the fault, as in other basement fault-cored anticlines [Stone, 1993] and not ahead of the upper tip line, as in the forced fold model.

[14] Deformation of basement rocks was also suggested by Blackstone [1986], Wise and Obi [1992], and Stone [1993]. In most kinematic models of basement fault-cored folds, the basement is assumed to be rigid [e.g., Stearns, 1978; Cosgrove and Ameen, 2000]. For example, in the trishear model [Erslev, 1991], deformation occurs exclusively in a triangular area ahead of the upper tip line of the fault. This non-physical assumption may produce a deformation that resembles that of physically-based models if there is no bedding-parallel slip and the fault is able to propagate in the cover [Niño et al., 1998; Cardozo et al., 2003] and if the cover is perfectly welded to the basement and the thrust fault is planar [Johnson and Johnson, 2002]. In the case of bedding-parallel slip [Niño et al., 1998], the fold develops above the thrust fault, in its hanging wall, contemporaneously with less efficient thrust fault propagation. At Sheep Mountain Anticline, for the fold to have developed above the thrust fault, we expect that some
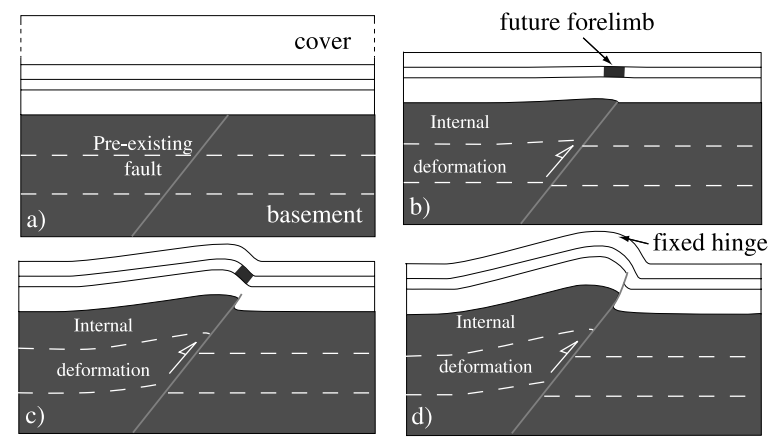

Figure 3. Conceptual model for basement fault-cored anticlines. (a) Pre-Laramide configuration. The thrust fault is inherited. (b) Onset of Laramide faulting. The basement starts deforming, as does the cover. Both are affected by the stress field perturbation resulting from the superposition of the slip related stresses and the shortening related stresses. (c) Fold initiation and (d) fold amplification with a fixed hinge and rotating limbs. The basement hangingwall block is internally deformed. The fault is represented as propagating through the cover. 
mixture of bed-parallel slip, relatively slow fault propagation through the cover, and heterogeneous mechanical properties, including internally deformable basement, was in existence during deformation. Our results support the observation [Blackstone, 1986; Wise and Obi, 1992; Stone, 1993] that a curved basement-cover interface does not necessarily imply that the fault propagated from below this interface as suggested by Bump [2003] and Garcia and Davis [2004] using trishear assumptions.

\section{Conclusions}

[15] Previously published fracture data show that early vertical joints parallel to the regional Laramide compression are rare in the forelimb of Sheep Mountain Anticline. We first show that early fracture patterns within basement-cored folds may have a spatially variable distribution. Threedimensional elastic models mechanically constrain the area where joints might be inhibited. We find that this area is located in the hanging wall of the thrust fault, just behind the upper fault tip line, which implies that the forelimb was in this location in the early stage of folding. This in turn largely constrains the early mode of folding. We show that the fold formed above the thrust fault and did not flex around its upper tip line as in forced fold models. Within the context of the idealized models considered here, we would conclude that the fold developed with a fixed hinge and rotating limbs and the basement was internally deformed in the thrust hangingwall.

[16] Acknowledgments. This paper benefited from discussions with M. Cooke, J.-M. Daniel, M. Guiton, Y. Leroy, L. Maerten, D. Stone, and T. Hauge. We thank I. Mynatt and Y. Fujii for assistance in the field. Reviews by P. Hennings and M. Cooke greatly improved the first version of this paper. This work was supported by the National Science Foundation Tectonics Program Grant EAR-012935 and the Collaboration in Mathematical Geosciences Program Grant No. EAR-04177521, the Stanford Rock Fracture Project, and the Institut Français du Pétrole.

\section{References}

Bellahsen, N., P. E. Fiore, and D. D. Pollard (2006), The role of fractures in the structural interpretation of Sheep Mountain anticline, Wyoming, J. Struct. Geol., in press.

Bieniawski, Z. T. (1984), Rock Mechanics Design in Mining and Tunneling, 272 pp., A. A. Balkema, Brookfield, Vt.

Bird, P. (2002), Stress direction history of the western United States and Mexico since 85 May, Tectonics, 21(3), 1014, doi:10.1029/ 2001 TC001319.

Blackstone, D., Jr. (1986), Structural geology, northwest margin, Bighorn Basin; Park County, Wyoming and Carbon County, Montana, in Geology of the Beartooth Uplift and Adjacent Basins, edited by P. B. Garrison, pp. 125-135, Yellowstone Bighorn Res. Assoc., Redlodge, Mont.

Boness, N. L., and M. D. Zoback (2004), Stress-induced seismic velocity anisotropy and physical properties in the SAFOD Pilot Hole in Parkfield, CA, Geophys. Res. Lett., 31, L15S17, doi:10.1029/ 2003GL019020

Bourne, S. J., and E. J. M. Willemse (2001), Elastic stress control on the pattern of tensile fracturing around a small fault network at Nash Point, UK, J. Struct. Geol., 23, 1753-1770.

Bump, A. (2003), Reactivation, trishear modeling, and folded basement in Laramide uplifts; implications for the origins of intra-continental faults, GSA Today, 13, 4-10.
Cardozo, N., K. Bhalla, A. T. Zehnder, and R. W. Allmendinger (2003), Mechanical models of fault propagation folds and comparison to the trishear kinematic model, J. Struct. Geol., 25, 1-18.

Casas, A. M., B. Oliva, T. Román-Berdiel, and E. Pueyo (2003), Basement deformation: Tertiary folding and fracturing of the Variscan Bielsa granite (Axial zone, central Pyrenees), Geod. Acta, 16, 99-117.

Cosgrove, J. W., and M. S. Ameen (2000), A comparison of the geometry, spatial organization and fracture patterns associated with forced folds and buckle folds, in Forced Folding and Fractures, edited by J. W. Cosgrove and M. S. Ameen, Geol. Soc. Spec. Publ., 169, 7-21.

Engebretson, D. C., A. Cox, and R. G. Gordon (1985), Relative motions between oceanic and continental plates in the Pacific Basin, Spec. Pap. Geol. Soc. Am., 206, 1-59.

Erslev, E. (1986), Basement balancing of Rocky Mountain foreland uplifts, Geology, 14, 259-262.

Erslev, E. A. (1991), Trishear fault-propagation folding, Geology, 19, 617620.

Forster, A., A. P. Irmen, and C. Vondra (1996), Structural interpretation of Sheep Mountain Anticline, Bighorn Basin, Wyoming, Wyoming Geological Association Guidebook, 47, 239-251.

Garcia, P. E., and G. H. Davis (2004), Evidence and mechanisms for folding of granite, Sierra de Hualfin basement-cored uplift, northwest Argentina, AAPG bulletin, 88, 1255-1276.

Hennier, J., and J. Spang (1983), Mechanisms for deformation of sedimentary strata at Sheep Mountain anticline, Big Horn Basin, Wyoming, Wyo. Geol. Assoc. Guideb., 34, 97-111.

Johnson, K. M., and A. M. Johnson (2002), Mechanical models of trishearlike folds, J. Struct. Geol., 24, 277-287.

Kattenhorn, S. A., A. Aydin, and D. D. Pollard (2000), Joints at high angles to normal fault strike: An explanation using 3-D numerical models of fault-perturbed stress fields, J. Struct. Geol., 22, 1-23.

Maerten, L., P. Gillespie, and D. D. Pollard (2002), Effects of local stress perturbation on secondary fault development, J. Struct. Geol., 24, 145153

Mavko, G., T. Mukerji, and J. Dvorkin (1998), The Rock Physics Handbook, 339 pp., Cambridge University Press, New York.

McConnell, D. (1994), Fixed-hinge, basement-involved fault-propagation folds, Wyoming, Geol. Soc. Am. Bull., 106, 1583-1593.

Niño, F., H. Philip, and J. Chéry (1998), The role of bed-parallel slip in the formation of blind thrust faults, J. Struct. Geol., 20, 503-516.

Reches, Z. (1978), Development of monoclines; part II, Theoretical analysis of monoclines, in Laramide Folding Associated With Basement Block Faulting in the Rocky Mountains Region, edited by V. Matthews, Mem. Geol. Soc. Am., 151, 273-311.

Rioux, R. (1994), Geologic map of the Sheep Mountain-Little Sheep Mountain area, Big Horn County, Wyoming. Scale 1:31,680, U. S. Geol. Surv. Open File Rep., 94-191.

Stanton, H. I., and E. A. Erslev (2004), Sheep Mountain: Backlimb tightening and sequential deformation in the Bighorn Basin, Wyoming, Wyo. Geol. Assoc. Guideb., 54, 75-87.

Stearns, D. (1978), Faulting and forced folding in the Rocky Mountains foreland, in Laramide Folding Associated With Basement Block Faulting in the Rocky Mountains Region, edited by V. Matthews, Mem. Geol. Soc. Am., 151, 1-37.

Stone, D. S. (1993), Basement-involved thrust-generated folds as seismically imaged in the subsurface of the central Rocky Mountain foreland, in Laramide basement Deformation in the Rocky Mountain Foreland of the Western United States, edited by C. J. Schmidt et al., Geol. Soc. Am. Spec. Pap., 280, 271-312.

Thomas, A. L. (1993), Poly3D: A three-dimensional, polygonal element, displacement discontinuity boundary element computer program with applications to fractures, faults, and cavities in the Earth's crust, M.S. thesis, Stanford Univ., Stanford, Calif.

Wise, D., and C. Obi (1992), Laramide basement deformation in an evolving stress field, Bighorn Mountain front, Five Springs area, Wyoming, AAPG Bull., 76, 1586-1600.

N. Bellahsen, Laboratoire de Tectonique, Université Pierre et Marie Curie, F-75252 Paris Cedex 05, France. (nicolas.bellahsen@lgs.jussieu.fr)

P. E. Fiore and D. D. Pollard, Department of Geological and Environmental Sciences, Stanford University, Stanford, CA 94305-2115, USA. 